\title{
CHARACTERIZATION OF PEANUT (Arachis hypogaea L.) GERMPLASM FOR MORPHOLOGICAL AND QUALITY TRAITS IN AN ARID ENVIRONMENT
}

\author{
Ahmad SHER ${ }^{l}$, Muhammad KASHIF ${ }^{l}$, Abdul SATTAR ${ }^{l}$, Abdul QAYYUM ${ }^{2}$, Sami UL-ALLAH ${ }^{*}$, Ahmad \\ $N A W A Z^{l}$ and Abdul MANAF \\ ${ }^{1}$ Bahauddin Zakariya University, College of Agriculture, Bahadur Sub-Campus Layyah, PAKISTAN \\ ${ }^{2}$ The University of Haripur, Department of Agronomy, PAKISTAN \\ ${ }^{3}$ University of Arid Agriculture, Department of Agronomy, PMAS, Rawalpindi, PAKISTAN \\ *Corresponding author: samipbg@bzu.edu.pk
}

Received: 20.02.2019

\begin{abstract}
Exploring the genetic variation is the base of peanut (Arachis hypogaea L.) breeding program since peanut is an important food legumes and oilseed crop of the world, but its breeding is neglected compared to major oilseed crops. A field study was conducted to characterize the genetic variation and correlation among important yield and quality related traits of peanut under arid climate conditions during two consecutive years 2015 and 2016. Results revealed that a higher genetic diversity is present among the tested genotypes with respect to pod yield, oil contents and fatty acid composition. The highest number of leaves per plant, pods per plant, seed weight, pod yield, oil contents and palmitic acid were recorded in genotype 'BARI-2011' as compared with the other peanut genotypes. However, 100-seed weight was the maximum in genotype 'Golden'. Among the years, the morphological, yield parameters, oil contents and palmitic acid was the higher in second year than those of the first year of experimentation. In conclusion, the high genetic variability has been found among the peanut germplasms may contribute to develop a high yielding variety with good seed quality.
\end{abstract}

Keywords: Arid environment, fatty acid, peanut, oil content, yield

\section{INTRODUCTION}

Peanut (Arachis hypogaea L.) is an important kharif oilseed crop which has an oil content of 50\%, and its seeds also contain surplus quantities of iron and vitamins A and B (Prasad et al., 2010; Arioglu et al., 2018; Dragičević et al., 2018; Yol and Uzun, 2018).

Now a day, peanut is cultivated in more than 40 countries including United States of America, China, Mayanmar, Argentina, India, Brazil, Pakistan, Sudan, Nigeria, Indonesia and Senegal being the top producers of peanut in the world. Among these countries, Pakistan is ranked at $7^{\text {th }}$ position for peanut production. In Pakistan, it is grown under rainfed conditions in the Pothwar plateau of Punjab (84\% in districts of Chakwal, Attock and Rawalpindi), Sindh (3\%) and Khyber Pakhtunkhwa (3\%) on an area 81.5 thousand hectares with annual production of 91.4 thousand tones (Government of Pakistan, 2018).

Peanut seed has several uses; oil extracted from its seeds is used for cooking purpose (Kudama, 2013. Arioglu et al., 2018). The remaining seed cake after oil extraction is used as feed for livestock. The extracted peanut oil after decolorization and deodorization is used for making vegetable butter i.e. margarine (Ahmadi and Shahmir, 2016). Its seeds after removing the outer seed covering are used to decorate the vegetable dishes. Peanut seeds are also used in bakery products (e.g. nimko mix) and after roasting used for serving the guests in homes along with other dry fruits.

Peanut cultivation is spreading in non-traditional areas like Thal region in Punjab, Pakistan due to very low input cost and high economic returns. Moreover, the soils of Thal regions are sandy loams which are best suited for peanut production. However, the average yield of peanut is low in Pakistan including Thal region. There are several factors which are responsible for low yield. These include drought and heat stresses, weeds, insect pests and diseases (Prasad et al., 2010). The reproductive and grain filling stages of peanut are more sensitive to abiotic stresses (Narayanan et al., 2015; Gulluoglu et al., 2018). Thus, there is a need to identify the superior germplasm which can be used in the future breeding programmes for maximizing its production under irrigated conditions. Yield attributes of peanut like pods per plant, seeds per pod and seed size trigger the market value of peanut in general. In addition, the selection of peanut cultivars 
during the hybridization experiments largely relied upon the performance of yield parameters (e.g. pods per plant, seeds per pod and seed weight) in the parent cultivars (Reddy et al., 1993; Zaman et al., 2011; Zurweller et al., 2018). Nutritional quality of peanut is also very important as storage capability of peanut mainly depends on concertation of saturated and unsaturated fatty acids like linoleic acid, oleic acid and plamatic acid (Gulluoglu et al., 2016). Saturated fatty acids vary from 10-17\% and unsaturated fatty acids vary $83-90 \%$ in different genotypes of the peanut (Chowdhury et al., 2015; Gulluoglu et al., 2016).

Thus, the present two-year study was conducted to characterize the peanut germplasm and to identify the superior peanut genotype in terms of yield and quality for enhancing its cultivation in the arid region.

\section{MATERIALS AND METHODS}

Site and Soil

This 2-year field study was conducted at research farm of College of Agriculture, Bahauddin Zakariya University, Bahadur Sub-Campus Layyah, (latitude of 30.9; longitude of 70.9 and altitude of $143 \mathrm{~m}$ above sea level) Pakistan in 2015-2016. The soil samples were collected prior to the sowing of the experiment during both years from experimental site. The soil was sandy loam. On an average, the experimental soil have electrical conductivity of $156 \mathrm{dS} \mathrm{m} \mathrm{m}^{-1}$, soil $\mathrm{pH}$ of 8.0 , soil organic matter of $0.69 \%$, available phosphorus of $9 \mathrm{ppm}$, potassium of 100 ppm, and nitrate-nitrogen of $1.6 \mathrm{mg} \mathrm{kg}^{1}{ }^{1}$ during both year of experimentation. The daily maximum and minimum temperature $\left({ }^{\circ} \mathrm{C}\right)$ and rainfall $(\mathrm{mm})$ recorded during the growth period of crop during both years are given in Table 1.

Table 1. Weather data during the experimental period

\begin{tabular}{lcccccc}
\hline & \multicolumn{2}{c}{ Maximum temperature $\left({ }^{\circ} \mathbf{C}\right)$} & \multicolumn{2}{c}{ Minimum } & temperature $\left({ }^{\circ} \mathbf{C}\right)$ & \multicolumn{2}{c}{ Rainfall $(\mathbf{m m})$} \\
\cline { 2 - 6 } & $\mathbf{2 0 1 5}$ & $\mathbf{2 0 1 6}$ & $\mathbf{2 0 1 5}$ & $\mathbf{2 0 1 6}$ & $\mathbf{2 0 1 5}$ & $\mathbf{2 0 1 6}$ \\
\hline April & 31.9 & 33.9 & 13.7 & 19.4 & 22 & 16 \\
May & 37.6 & 40.7 & 21.4 & 25.3 & 18 & 1 \\
June & 39.8 & 41.6 & 26.3 & 28.8 & 00 & 36 \\
July & 36.6 & 37.0 & 27.1 & 27.0 & 165 & 85 \\
August & 38.6 & 36.7 & 27.2 & 26.3 & 21 & 61 \\
September & 37.9 & 35.5 & 24.12 & 24.7 & 20 & 61 \\
\hline
\end{tabular}

Eight peanut genotypes viz., 12CG001, 12CG002, 12CG003, 12CG005, 12CG007, 12CG009, Golden and BARI-2011 were collected from Barani Agricultural Research Institute (BARI), Chakwal, Pakistan.

The experiment was laid out in a randomized complete black design (RCBD) having three replications with a net plot size of $3.2 \mathrm{~m} \times 6 \mathrm{~m}$. Row to row distance was maintained at $45 \mathrm{~cm}$; the plant to plant distance was 15 $\mathrm{cm}$.

\section{Land Preparation, Sowing and Crop Husbandry}

The site of experimentation was previously under a cotton-wheat rotation. Prior to sowing, pre sowing irrigation was applied to bring soil at workable moisture to facilitate the seed germination. The seedbed was prepared with two cultivations followed by two plankings (levelling of land). The crop was sown with locally manufactured hand drill on April 15, 2015 and April 17, 2016 using a seed rate of $100 \mathrm{~kg} \mathrm{ha}^{-1}$. Fertilizer dose of $30 \mathrm{~kg} \mathrm{~N} \mathrm{ha}^{-1}$ and $70 \mathrm{~kg} \mathrm{P}_{2} \mathrm{O}_{5} \mathrm{ha}^{-1}$ was broadcasted prior to seedbed preparation. Manual hoeing was done to eradicate the weeds. Crop was harvested on September 29, 2015 and September 30, 2016 with the help of a manual digger.

\section{Data Recording and Statistical Analysis}

The numbers of pods and number of leaves per plant of twenty plants from each plot at harvest were counted and averaged. The pods yield of each plot was recorded after drying the pods for two weeks after sun-drying. The pods were shelled manually. The obtained seeds after shelling were weighed for each plot, later expressed in $\mathrm{kg}$ $\mathrm{ha}^{-1}$. Three sub-samples of 100-seeds were taken from the seed lot of each plot and were weighed on an electric balance to work out 100-seed weight. The shelling percentage was recorded as: [weight of shelled seeds /weight of unshelled pods] $\times 100$. The oil contents of shelled seeds were determined following the procedure of (Warnsely, 1998). The fatty acids composition (palmitic acid, oleic acid and linoleic acids) were analyzed using the gas chromatograph technique after inter-sterilification with methanolic KOH (Paquot, 1988). The data collected on all parameters was subjected to analysis of variance technique to found the statistical differences between the treatments means. For analysis, the year was taken as an individual factor and the data was analyzed in randomized complete block design in factorial arrangement. If the statistically significant differences were detected between two years or among the peanut genotypes, the least significant difference test at $5 \%$ probability test was used to differentiate between mean values of years, genotypes or interaction (Steel et al., 1997).

\section{RESULTS}

\section{Yield Parameters}

This study indicated that different peanut genotypes differed for number of leaves per plant, pods per plant, 100-seed weight, pod yield, seed weight and shelling percentage. Year effect was also significant for number of leaves/pods per plant, 100-seed weight and pod yield; results being non-significant for seed weight and shelling percentage. The interaction (year $\times$ genotype) was also significant for pod yield and number of pods per plant; 
results being non-significant for number of leaves per plant, 100-seed weight, seed weight and shelling percentage (Table 2). The highest number of leaves per plant, pods per plant, pod yield and seed weight were recorded in genotype BARI-2011. However, 100- seed weight was the highest in genotype Golden which was statistically similar with genotype12CG001. The shelling percentage was significantly higher but similar in genotypes BARI-2011, 12CG005 and 12CG007 (Table 2). Among the years, the number of leaves/pods per plant, pod yield and 100-seed weight were the highest during the second year of experimentation (Table 2). The interaction (year $\times$ genotype) showed that the highest numbers of pods per plant were recorded in genotype BARI-2011 during the first/second year of experimentation which was statistically similar with the genotype 12CG005 during the first year of experimentation. The pod yield was the highest in genotype BARI-2011 during the first year of experimentation (Table 2).

Table 2. Differences in number of pods per plant, number of leaves per plant, 100-seed weight, pod yield, seed yield and shelling percentage of various peanut genotypes in two years

\begin{tabular}{|c|c|c|c|c|c|c|}
\hline Treatments & 2015 & 2016 & Mean (G) & 2015 & 2016 & Mean (G) \\
\hline & \multicolumn{3}{|c|}{ Number of pods per plant } & \multicolumn{3}{|c|}{ Number of leaves per plant } \\
\hline $12 \mathrm{CG} 001$ & $10.5 \mathrm{f}$ & $13.9 \mathrm{ef}$ & $12.2 \mathrm{~F}$ & 516 & 465 & $490 \mathrm{E}$ \\
\hline $12 \mathrm{CG} 002$ & $15.3 \mathrm{ef}$ & $14.3 \mathrm{ef}$ & $14.8 \mathrm{EF}$ & 442 & 369 & $406 \mathrm{E}$ \\
\hline $12 \mathrm{CG} 003$ & $25.5 \mathrm{~d}$ & $19.2 \mathrm{e}$ & $22.3 \mathrm{D}$ & 1212 & 1203 & $1208 \mathrm{C}$ \\
\hline 12CG009 & $18.6 \mathrm{e}$ & $17.1 \mathrm{e}$ & $17.8 \mathrm{E}$ & 469 & 422 & $446 \mathrm{E}$ \\
\hline 12CG005 & $54.9 \mathrm{a}$ & $46.0 \mathrm{~b}$ & $50.5 \mathrm{~B}$ & 1077 & 1008 & 1042D \\
\hline BARI-2011 & $56.8 \mathrm{a}$ & $53.1 \mathrm{a}$ & $54.9 \mathrm{~A}$ & 1426 & 1392 & 1409B \\
\hline 12CG007 & $46.0 \mathrm{~b}$ & $39.2 \mathrm{c}$ & $42.6 \mathrm{C}$ & 1780 & 1646 & $1713 \mathrm{~A}$ \\
\hline Golden & $56.0 \mathrm{a}$ & $43.7 \mathrm{bc}$ & $49.8 \mathrm{~B}$ & 1106 & 1077 & 1092D \\
\hline Mean $(Y)$ & $35.4 \mathrm{~A}$ & $30.8 \mathrm{~B}$ & & $1004 \mathrm{~A}$ & $948 B$ & \\
\hline \multirow[t]{2}{*}{$\operatorname{LSD}(p \leq 0.05)$} & \multicolumn{3}{|c|}{$\mathrm{L}=4.23 ; \mathrm{Y}=2.11 ; \mathrm{L} \times \mathrm{Y}=5.98$} & \multicolumn{3}{|c|}{$\mathrm{L}=; 94 ; \mathrm{Y}=47$} \\
\hline & \multicolumn{3}{|c|}{ 100-seed weight $(\mathrm{g})$} & \multicolumn{3}{|c|}{ Pod yield $\left(\mathrm{Mg} \mathrm{ha}^{-1}\right)$} \\
\hline $12 \mathrm{CG} 001$ & 67.2 & 59.2 & $63.2 \mathrm{AB}$ & $2.2 \mathrm{~g}$ & $1.8 \mathrm{~g}$ & $2.0 \mathrm{E}$ \\
\hline $12 \mathrm{CG} 002$ & 65.4 & 56.6 & $61.0 \mathrm{~B}$ & $2.1 \mathrm{~g}$ & $2.0 \mathrm{~g}$ & $2.1 \mathrm{E}$ \\
\hline $12 \mathrm{CG} 003$ & 49.5 & 42.2 & $45.8 \mathrm{C}$ & $3.9 \mathrm{f}$ & $4.6 \mathrm{f}$ & 4.3D \\
\hline $12 \mathrm{CG} 009$ & 53.9 & 45.6 & $49.8 \mathrm{C}$ & $2.6 \mathrm{~g}$ & $2.3 \mathrm{~g}$ & $2.4 \mathrm{E}$ \\
\hline $12 \mathrm{CG} 005$ & 48.1 & 44.1 & $46.1 \mathrm{C}$ & $10.5 b$ & $9.3 \mathrm{~cd}$ & $9.9 \mathrm{~B}$ \\
\hline BARI-2011 & 48.0 & 45.3 & $46.6 \mathrm{C}$ & $11.6 \mathrm{a}$ & $10.4 b$ & $11.0 \mathrm{~A}$ \\
\hline $12 \mathrm{CG} 007$ & 49.8 & 46.9 & $48.3 \mathrm{C}$ & $10.2 b c$ & $8.3 \mathrm{de}$ & $9.2 \mathrm{~B}$ \\
\hline Golden & 70.3 & 65.3 & $67.8 \mathrm{~A}$ & $9.1 \mathrm{~d}$ & $7.8 \mathrm{e}$ & $8.5 \mathrm{C}$ \\
\hline Mean $(\mathrm{Y})$ & $56.5 \mathrm{~A}$ & $50.7 \mathrm{~B}$ & & $6.5 \mathrm{~A}$ & $5.8 \mathrm{~B}$ & \\
\hline \multirow[t]{2}{*}{$\operatorname{LSD}(\mathrm{p} \leq 0.05)$} & \multicolumn{3}{|c|}{$\mathrm{L}=5.3 ; \mathrm{Y}=2.6$} & \multicolumn{3}{|c|}{$\mathrm{L}=0.76 ; \mathrm{Y}=0.38 ; \mathrm{L} \times \mathrm{Y}=1.07$} \\
\hline & \multicolumn{3}{|c|}{ Seed weight $\left(\mathrm{Mg} \mathrm{ha}^{-1}\right)$} & \multicolumn{3}{|c|}{ Shelling percentage $(\%)$} \\
\hline 12CG001 & 1.6 & $1.2^{\circ}$ & $1.4 \mathrm{E}$ & 70.7 & 67.1 & 68.9BC \\
\hline 12CG002 & 1.5 & 1.4 & $1.4 \mathrm{E}$ & 69.3 & 68.8 & $69.0 \mathrm{~B}$ \\
\hline $12 \mathrm{CG} 003$ & 2.7 & 3.1 & 2.9D & 67.7 & 68.9 & $68.3 \mathrm{C}$ \\
\hline 12CG009 & 1.7 & 1.5 & $1.6 \mathrm{E}$ & 65.0 & 66.8 & $65.9 \mathrm{D}$ \\
\hline 12CG005 & 7.3 & 7.0 & $7.1 \mathrm{~B}$ & 69.6 & 75.1 & $72.4 \mathrm{~A}$ \\
\hline BARI-2011 & 8.1 & 7.8 & $8.0 \mathrm{~A}$ & 70.2 & 75.3 & $72.8 \mathrm{~A}$ \\
\hline $12 \mathrm{CG} 007$ & 7.2 & 6.2 & $6.7 \mathrm{~B}$ & 70.1 & 75.2 & $72.6 \mathrm{~A}$ \\
\hline Golden & 6.0 & 5.7 & $5.9 \mathrm{C}$ & 66.2 & 72.8 & $69.5 \mathrm{~B}$ \\
\hline Mean $(Y)$ & 4.5 & 4.2 & & 68.6 & 71.2 & \\
\hline $\operatorname{LSD}(\mathrm{p} \leq 0.05)$ & $\mathrm{L}=; 0.5$ & & & $\mathrm{~L}=0.52$ & & \\
\hline
\end{tabular}

Means of main effects and interaction sharing the same case letter for a parameter do not differ significantly at $\mathrm{p} \leq 0.05$; $\mathrm{G}=\mathrm{peanut}$ genotypes; $\mathrm{Y}=$ year

\section{Quality Parameters}

Different peanut genotypes differed for oil contents and fatty acid (palmitic acid, oleic acid, linoleic acid) composition. Year effect was also significant for oil contents and palmitic acid; results being non-significant for linoleic acid and oleic acid. The interaction (year $x$ genotype) was non-significant for oil contents, palmitic acid, oleic acid and linoleic acid (Table 3). Among the peanut genotypes, the highest oil contents and palmitic acid were recorded in genotype BARI-2011 which was statistically similar with genotype Golden for oil contents. The oleic acid was the highest but statistically similar in genotypes 12CG009, 12CG005, BARI-2011, 12CG007 and Golden. However, the highest linoleic was recorded in genotype 12CG003 which was statistically similar with genotype 12CG001, 12CG002 and 12CG007. Among the years, the highest oil contents and palmitic acid were recorded during the second year of experimentation (Table). 
Table 3. Differences in oil contents and fatty acid composition of various peanut genotypes in two years

\begin{tabular}{|c|c|c|c|c|c|c|}
\hline Treatments & 2015 & 2016 & Mean (G) & 2015 & 2016 & Mean (G) \\
\hline & \multicolumn{3}{|c|}{ Oil contents (\%) } & \multicolumn{3}{|c|}{ Palmitic acid (\%) } \\
\hline 12CG001 & 49.1 & 48.8 & $48.9 \mathrm{E}$ & 10.04 & 9.21 & $9.62 \mathrm{D}$ \\
\hline 12CG002 & 50.2 & 49.2 & 49.7DE & 9.63 & 9.64 & $9.64 \mathrm{D}$ \\
\hline $12 \mathrm{CG} 003$ & 51.7 & 50.0 & $50.8 \mathrm{BCD}$ & 9.71 & 8.64 & $9.18 \mathrm{D}$ \\
\hline 12CG009 & 50.9 & 49.5 & $50.2 \mathrm{CDE}$ & 9.88 & 9.84 & $9.86 \mathrm{CD}$ \\
\hline 12CG005 & 51.1 & 51.3 & $51.2 \mathrm{ABC}$ & 11.59 & 10.06 & $10.83 \mathrm{~B}$ \\
\hline BARI-2011 & 53.7 & 51.2 & $52.5 \mathrm{~A}$ & 11.83 & 12.13 & $11.98 \mathrm{~A}$ \\
\hline $12 \mathrm{CG} 007$ & 52.7 & 50.5 & $51.6 \mathrm{ABC}$ & 10.68 & 10.14 & $10.41 \mathrm{BC}$ \\
\hline Golden & 52.4 & 51.5 & $51.9 \mathrm{AB}$ & 11.34 & 9.84 & $10.59 \mathrm{~B}$ \\
\hline Mean (Y) & $51.5 \mathrm{~A}$ & $50.2 \mathrm{~B}$ & & $10.59 \mathrm{~A}$ & 9.94B & \\
\hline \multirow[t]{2}{*}{$\operatorname{LSD}(p \leq 0.05)$} & \multicolumn{3}{|c|}{$\mathrm{L}=; 1.51 \mathrm{Y}=0.76$} & \multicolumn{3}{|c|}{$\mathrm{L}=0.69 ; \mathrm{Y}=0.34$} \\
\hline & \multicolumn{3}{|c|}{ Oleic acid (\%) } & \multicolumn{3}{|c|}{ Linoleic acid (\%) } \\
\hline 12CG001 & 48.4 & 48.5 & $48.5 \mathrm{~B}$ & 31.7 & 34.4 & $33.1 \mathrm{AB}$ \\
\hline $12 \mathrm{CG} 002$ & 48.5 & 47.8 & $48.2 \mathrm{~B}$ & 34.2 & 34.0 & $34.1 \mathrm{AB}$ \\
\hline $12 \mathrm{CG} 003$ & 48.5 & 47.7 & $48.1 \mathrm{~B}$ & 33.1 & 37.4 & $35.3 \mathrm{~A}$ \\
\hline 12CG009 & 50.2 & 49.7 & $50.0 \mathrm{~A}$ & 30.9 & 29.5 & $30.2 \mathrm{CD}$ \\
\hline 12CG005 & 49.9 & 50.6 & $50.3 \mathrm{~A}$ & 29.4 & 29.5 & $29.4 \mathrm{CD}$ \\
\hline BARI-2011 & 51.5 & 49.7 & $50.6 \mathrm{~A}$ & 28.6 & 28.9 & $28.7 \mathrm{D}$ \\
\hline 12CG007 & 50.5 & 49.2 & $49.9 \mathrm{~A}$ & 33.8 & 33.1 & $33.5 \mathrm{AB}$ \\
\hline Golden & 50.2 & 49.6 & $49.9 \mathrm{~A}$ & 31.7 & 31.6 & 31.7BC \\
\hline Mean (Y) & 49.7 & 49.1 & & 31.7 & 32.3 & \\
\hline $\operatorname{LSD}(p \leq 0.05)$ & $\mathrm{L}=1.3 \xi$ & & & $\mathrm{L}=2.57$ & & \\
\hline
\end{tabular}

\section{Correlation analyses}

Correlation analyses depicted variable strength of association among different traits (Table 4). Number of leaves showed strong correlation with other leave traits like pod yield, seed weight, and number of pods. Linoleic acid does not show significant correlation with any other trait.

Table 4. Co-relation coefficients of various yield parameters with seed yield

\begin{tabular}{lllll}
\hline & Pod yield & Seed yield & Shelling percentage & Linoleic acid \\
\hline Number of pods & $0.95^{* *}$ & $0.94^{* *}$ & $0.23 \mathrm{~ns}$ & - \\
Number of leaves & $0.81^{* *}$ & $0.80^{* *}$ & $0.30 \mathrm{~ns}$ & - \\
Oleic acid & - & - & - & $-0.44^{*}$ \\
\hline
\end{tabular}

\section{DISCUSSION}

The results of this study showed that different peanut genotypes differed for morphological and yield parameters, pod/seed yield, shelling percentage, oil contents and fatty acid composition. Indeed, the programs of the plant genetic improvement are dependent upon the diversity and selection of suitable genotypes for an area (Sadeghi et al., 2011; Gulluoglu et al., 2017; Zurweller et al., 2018). Although, peanut is a self-pollinating crop and shows limited variability for morphological and yield parameters (Jeyaramraja and Woldesenbet, 2014; Cemal et al., 2017; Onat et al., 2017), nonetheless, the statistically significant differences for morphological and yield parameters, pod/seed yield, shelling percentage, oil contents and fatty acid composition among the studied peanut genotypes in this study indicated the existence of a greater genetic diversity in these genotypes for studied traits grown under an arid climate in Pakistan. The significant differences in morphological, yield parameters, oil contents and fatty acid composition in studied peanut genotypes might be attributed to the differences in the genetic makeup of a genotype (bunch or erect), its origin and the weather conditions which prevailed during the crop life cycle (Hassan and Ahmed, 2012; Abate et al., 2015). The reported genetic diversity can be utilized in further breeding programs to breed high yielding peanut genotype for arid climates.

Among the peanut genotypes, the highest pod and seed weight was recorded in genotype BARI-2011. Improvement in seed and pod yield in this genotype might be attributed to more number of leaves/pods per plant in this genotype than the other genotypes which produced less number of leaves and minimum number of pods per plant which resulted in low seed and pod yield (Janila et al., 2013a). The 100-seed weight was the highest in genotype Golden. Indeed, the seed size of Golden genotype is bold as compared with other genotypes (Naeem-ud-Din et al., 2009; Yol and Uzun, 2018) which eventually enhanced the 100-seed weight in this study.

Various genotypes differed for oil contents and fatty acid composition. The oil contents and palmatic acid were 
the highest in genotype BARI-2011. Indeed, the oil contents of genotypes are affected by the production location, growing season, soil temperature, soil moisture and soil fertilization (Dwivedi et al., 1996; Singkham et al., 2010; Boydak et al., 2010; Arioglu et al., 2016; Zurweller et al., 2018) and the same was observed in this study.

There existed a strong correlation of number of leaves/pods per plant with seed and pod yield (Table 4). The number of pods per plant is an important yield contributing traits. It is well known that as the number of pods per plant in legumes is increased, the seed yield also increases provided that the seed formation and seed size within the pods are not limited by crop management and biotic/abiotic stresses. Moreover, the production of higher number of leaves in peanut genotypes also resulted in better canopy development and leaf area which lead to better yield. Indeed, the leaves of peanut are small as compared to other legumes, thus increase in number of leaves is useful for harvesting maximum photosynthetic radiation in peanut. The leaves act as photosynthetic machinery. Thus, the higher number of leaves in peanut resulted in more photosynthesis which might have improved the source to sink relationship and finally the pod/seed yield in this study. Strong positive or negative correlation among traits helps breeders to devise a selection criterion for development of high yielding genotypes (Hassan et al., 2007, 2011).

The morphological/yield parameters, pod yield and oil contents were the highest during first year of experimentation which might be attributed to excessive rainfall in the month of July which facilitated the flowering and pegging in peanut.

In conclusion, there is an existence of greater genetic diversity in the tested genotypes under the arid climate which might be exploited in future breeding programs for developing new peanut genotypes to get maximum production of peanut under arid climates. From the existed germplasm BARI-2011 proved best for high production of peanut in arid climate.

\section{LITERATURE CITED}

Abate, M., F. Mekbib, A. Ayana and M. Nigussie. 2015 Genotype $\times$ environment and stability analysis of oil content in sesame (Sesamun indicum L.) evaluated across diverse agro-ecologies of Awash Valleys in Ethiopia. Am. J. Exp. Agric. 9(2): 1-12.

Ahmadi, L. and F. Shahmir. 2016. Physical characteristics of peanut butter influenced by fully hydrogenated flix weed seed oil (Descurainia sophia L.) as a stabilizer. Am. J. Oil Chem. Soc. 93(5): 743-746.

Arioglu, H., H. Bakal, L. Gulluoglu, O. Bihter and K. Cemal. 2018. The effect of harvesting dates on some agronomic and quality characteristics of peanut (Arachis hypogaea L.) varieties grown as a main crop in Mediterranean region (Turkey). Turk J Field Crops. 23(1): 27-37.

Boydak, E., D. Karaaslan and H. Turkoglu. 2010. The effect of different nitrogen and irrigation levels on fatty acid composition of peanut oils. Turk J Field Crops. 15(1): 29-33.

Cemal, K., H. Bakal, L. Gulluoglu and H. Arioglu. 2017. The Effect of twin row planting pattern and plant population on yield and yield components of peanut (Arachis hypogaea L.) at main crop planting in Cukurova region of Turkey. Turk $\mathbf{J}$ Field Crops. 22(1): 24-31.

Chowdhury, F.N., D. Hossain, M. Hosen and S. Rahman. 2015. Comparative Study on Chemical Composition of Five Varieties of Groundnut (Arachis hypogeal L.). World J. of Agricultural Science 11(5): 247-254.

Dragicevc, V., S. Kratovalieva, Z. Dimov, V. Babic, B. Kresovic and N. Kravic. 2018. Potential bioavailability of calcium, magnesium, iron, manganese and zinc from seeds of different chickpea and peanut landraces. J. Elementol. 23(1): 273-85.

Dwivedi, S.L., S.N. Nigam, R. Jambunathan, K.L. Sahrawat, G.V.S. Nagabhushanam and K. Raghunath. 1993. Effect of genotypes and environments on oil content and oil quality parameters and their correlation in peanut (Arachis hypogaea L.). Peanut Sci. 20: 84-89.

Dwivedi, S.L., S.N. Nigam, R.C.N. Rao, R. Singh and K.V.S. Rao. 1996. Effect of drought on oil, fatty acids and protein contents of groundnut (Arachis hypogaea L.) seeds. Field Crop Res. 48: 125-133.

Gulluoglu, L., H. Arioglu, H, Bakal and O. Bihter. 2018. Effect of high air and soil temperature on yield and some yield components of peanut (Arachis hypogaea L.). Turk J Field Crops 23(1): 62-71.

Gulluoglu, L., H. Bakal, O. Bihter, K. Cemal and H. Arioglu. 2017. Comparison of agronomic and quality characteristics of some peanut (Arachis hypogaea L.) varieties grown as main and double crop in Mediterranean region. Turk J Field Crops. 22(2): 166-177.

Hassan, F.U., A. Manaf, G. Qadir and S.M.A. Basra. 2007. Effects of sulphur on seed yield, oil, protein and glucosinolates of canola cultivars. Int. J. Agri. Biol. 9: 504509.

Hassan, F.U. and M. Ahmed. 2012. Oil and fatty acid composition of peanut cultivars grown in Pakistan. Pak. J. Bot. 44: 627-630.

Hassan, F.U., S. Kaleem and M. Ahmad. 2011. Oil and fatty acid distribution in different circles of sunflower head. J. Food Chem. 128: 590-595.

Janila, P., S.N. Nigam, M.K. Pandey, P. Nagesh and R.K. Varshney. 2013a. Groundnut improvement: use of genetic and genomic tools. J. Frontier Plant Sci. 4(23): doi: 10.3389/fpls.2013.00023. PMCID: PMC3580887.

Jeyaramraja, P.R. and F. Woldesenbet. 2014. Characterization of yield components in certain groundnut (Arachis hypogaea L.) varieties of Ethiopia. J. Exp. Biol. Agri. Sci. 2:23208694.

Kudama, G. 2013. Economics of Groundnut Production in East Hararghe Zone of Oromia Regional State, Ethiopia. Sci. Tech. Arts. Res. J. 2: 135-13.

Naeem, U., A. Mahmood, G.S.S. Khattak, I. Saeed and M.F. Hassan. 2009. High yielding groundnut (Arachis hypogea L.) variety “Golden". Pak. J. Bot. 41: 2217-2222.

Narayanan, S., P.V.V. Prasad, A.K. Fritz, D.L. Boyle and B.S. Gill. 2015. Impact of high nighttime and high daytime temperature stress on winter wheat. J. Agron. Crop Sci. 201: 206-218.

Onat, B., H. Bakal, L. Gulluoglu, and H. Arroglu. 2016. The effects of row spacing and plant density on yield and yield components of peanut grown as a double crop in Mediterranean environment in Turkey. Turk J Field Crops. 22(1): 71-80

Paquot. 1988. Standard Methods for Analysis of Oils, Fats and Derivates. Paris France Pergamon Press p. 178.

Prasad, P., V.G. Kaka and H.D. Upadhyaya. 2010. Growth and production of groundnut. UNESCO Encyclopedia pp. 1-26. 
Reddy, L.J., S.N. Nigam, P. Subrahmanyam and R.G.S. Reddy. 1993. Registration of ICGV-86590 peanut cultivar. Crop Sci. 33:357-358.

Sadeghi, S.M., F. Javid and S.A.N. Niyaki. 2011. Assessment of genetic diversity in peanut (Arachis hypogaea L.) genotypes using quantitative traits by cluster analysis method. Res. J. Biol. Sci. 6:293-297.

Sheirdil, R.A., A. Mahmood, R.U. Khan, R. Khalid and U. Amara. 2016. Groundnut a crop for subsistence in edible oil production in Pakistan.https://agrihunt.com/articles/majorcrops/groundnut-a-crop-for-subsistence-in-edible-oilproduction-in-pakistan/ (last accessed on 20.04.2019)

Singkham, N., S. Jogloy, T. Kesmala, P. Swatsitang, P. Jaisil and N. Puppala. 2010. Genotypic variability and genotype by environment interactions in oil and fatty acids in high, intermediate and low oleic acid peanut genotypes. J. Agric. Food Chem. 58: 6257-6263.
Steel, R.G.D., J.A. Torrie and D.A. Dickey. 1997. Principles and procedures of statistics. A. Biometrical Approach 3rd Edi. Mc Graw Hill Book.INC. N.Y.

Warnsely, J. 1998. Simultaneous determination of oil and moisture in seed by Nmr. Lipid Tech. 10: 6.

Yol, E. and B. Uzun. 2018. Influences of genotype and location interactions on oil, fatty acids and agronomical properties of groundnuts. Grasas y Aceites 69(4): 276.

Zaman, M.A., K. Tuhina, M. Ullah, M.Z. Moniruzzamn and K.H. Alam. 2011. Genetic variability and path analysis of groundnut (Arachis hypogaea L.). The Agric. 9: 29-36.

Zurweller, B.A., A. Xavier, B.L. Tillman, J.R. Mahan, P.R. Payton, N. Puppala and D.L. Rowland. 2018. Pod yield performance and stability of peanut genotypes under differing soil water and regional conditions. J. Crop Improve. 32(4): 532-51. 